\title{
A Set of New Interpretations in Political Thought
}

\author{
Jan-Erik Lane \\ Public Policy Institute, Belgrade, Serbia \\ Email: janeriklane34@googlemail.com
}

How to cite this paper: Lane, J.-E. (2017) A Set of New Interpretations in Political Thought. Open Access Library Journal, 4: e3888.

https://doi.org/10.4236/oalib.1103888

Received: August 15, 2017

Accepted: September 12, 2017

Published: September 15, 2017

Copyright ( 2017 by author and Open Access Library Inc.

This work is licensed under the Creative Commons Attribution International License (CC BY 4.0).

http://creativecommons.org/licenses/by/4.0/

\begin{abstract}
One may approach the history of political thought through a variety of themes that various philosophers share but handle very differently. I wish here to capture a few trends in political thought by analysis of the following two long lived themes, namely: naturalism against moralism as well as determinism versus voluntarism.
\end{abstract}

\section{Subject Areas}

Philosophy, Politics

\section{Keywords}

Epicurism, Stoicism, Grotius, Spinoza, Helvetius, Holbach, Kierkegaard, Nietzsche, Rawls, and Dworkin

\section{Introduction}

The history of political thought may be arranged along certain major themes that recur from the Ancients to the Post-moderns [1]. Here, I have chosen two such themes, often encountered among the major political philosophers [2]. They are:

a) Moralism against naturalism: Are humans driven by the aim to validate inalienable rights or is needs, power and force the main drive?

b) Determinism versus voluntarism: Do humans exercise free will when e.g. setting up and running polities. Or is their behaviour determined by forces-micro or macro-beyond their control?

Of course, there are several other interesting themes to be found in the history of political theory, but these two can certainly be said to have dominated the debate with several political philosophers, some of whom will be analyzed 
in this paper. There are excellent examinations of the theme of determinism-indeterminism outside of the social world and humanity, to which I will add nothing here. One may debate whether determinism or indeterminism is warranted from an ontological or epistemological point of view [3].

In this paper I will put forward the following fresh arguments:

1) Stoicism against Epicurism is the great division in Ancient moral philosophy;

2) Grotius re-invigorates Stocism that lasts up to the modern philosopher of natural law: Nozick and Dworkin;

3) Spinoza maintains naturalism and determinism, but enters voluntarism in his political theory about institutionalism, somewhat inconsistently though;

4) Helvetius and Holbach are coherent materialists and determinists;

5) Kierkegaard is the greatest philosopher of the freedom of the will;

6) Nietzsche is a major voluntarist with a somewhat inhuman message;

7) Liberal egalitarianism is highly moralistic like Dworkin, except Rawls.

\section{Voluntarism against Determinism}

However one phrases this opposition-indeterminism versus determinism, voluntarism against predetermination-one ends up with the classical problem of the freedom of the will. The question of determinism against indeterminism deals not only with the interpretation of human behaviour and the history of mankind. The same problem is discussed about natural phenomena, like the evolution of the universe and of biological species. The contradiction between macro physics and micro physics is one version of this question, resulting in heated debate between Einstein and quantum physicists about determinism against indeterminism [4]. Here, we deal only with human behaviour and its question of free will.

Scholars who deny the existence of free will refer to either micro causation or macro causation. The first theory claims that human behaviour is driven by strong forces that humans only control to some extent, like emotions, needs, power, prestige, hidden motives etc. Reason can to some degree direct needs and emotions, as in the theory of enlightened self-interests.

The second theory focuses upon macro causation, explaining human behaviour with historical, economic or social forces, which constrain activities to such an extent that there is not set of choice opportunities. Such forces include nationalism, dialectical materialism, religious fanaticism, capitalism's inevitable path, history's development law, group pressure, etc. [5].

Against determinism as a theory about human behaviour, one may adduce game theory, which spells out the theoretical implications of human choice [6]. Determinism would have to counter that the parameters of rational choicepreferences and information-are in reality strictly determined by factors outside, outlines either in the micro or the macro approaches [7].

\section{Nature's Laws against Natural Law}

In the nowadays huge literature on the political theory of the $16^{\text {th }} 17^{\text {th }}$, and $18^{\text {th }}$ 
century's, one finds several neat and fruitful distinctions [8] (Skinner, 1979; Tuck, 1993; Plamenatz, 2012). For my aim, the distinction between two concepts of Nature is critical [9].

Thus, when for instance Hobbes and Locke are said to have different views on "Nature"-their staring-point for argumentation, it is bypassed that they refer to entirely different things with this label [10]. The same holds for Spinoza and Rousseau as well as other philosophers.

Several of the classics speak about "Nature", but they refer to one of two different entities: a) the physical nature or Universe, and b) humanity, or the human species. The classics from Lipsius to Kant debate the laws of "Nature", but the same distinction reappears with a vengeance, namely:

a) Nature's regularities-scientific laws, or law-like generalization-the mechanistic conception with Hobbes [11];

b) Norms: The fundamental legislation for human beings, i.e. moral laws as revealed by reason, divine revelation or human contract-the Grotius' conception [12].

Not separating between a) and b) is conducive to misunderstanding, confusing two different kinds of human rights, namely: a) each individual's drive to survive, fight and seek power and wealth-human real nature = IS; b) rights as moral obligations, i.e. claims, privileges, competences and immunities = OUGHT [13].

Now, one may argue that moralism entails indeterminism-Ought implies Can [14], whereas naturalism implies determinism. But let us look at some major political philosophers from this $2 \times 2$ Table with four possible combinations:

The key problem for research into political ideas is, of course, if some of these combinations present logical types, i.e. type I and Type IV are the coherent ones. Perhaps not, i.e. also types II and III could be coherent combinations of themes. We discuss this, when we place scholars like Spinoza, Helvetius, Holbach, Kierkegaard, Nietsche, and modern liberal egalitarians into this basic $2 \times 2 \mathrm{Ta}$ ble.

\section{The Origins of Distinctions: Stoicism against Epicurism}

The origins of the distinction introduced in Table 1 are to be found in Greek-Roman philosophy from the Ancient period, especially with the Pre-Socrates and the Post-Socrates. Although most of the writings or manuscripts have been lost, one may draw an opposition between the Epicureans and the Stoicists [15] [16].

Table 1. A few major themes in political thought.

\begin{tabular}{cccc}
\hline & & \multicolumn{3}{c}{ Causation } \\
\cline { 3 - 4 } & & Voluntarism & Determinism \\
\hline \multirow{2}{*}{ Morals } & Natural law & I & II \\
& Naturalism & III & IV \\
\hline
\end{tabular}


One school had its core in atomism (Demokritos) and adhered to its implications, such as determinism and naturalism. The Universe followed its laws and humans were driven by the search for pleasure and the avoidance of pain. Only reason could the emotions towards enlightened self-interest seeking. Human life was basically determined just as nature, but the consolation was given by reason, recommending a life in emotional balance of rational insight. However, the determinism of early atomism was reinterpreted to allow for an amount of indeterminism that opened up for free will.

The other school had spiritual origins, which made it attractive to later Christian theology. The entire world is a soul, which humans are members of. This soul is a gigantic community of everything, nature and living organisms. To be a member renders every human immunities, i.e. the human rights from sociability. Life consists of reflecting over this universal soul and research harmony by accepting Stoicist virtues. Stoicism is deterministic as well as spiritual.

The question of how determinism is to be interpreted in Ancient philosophy has been the topic of a large debate, where one has observed that both epicurism and stoicism developed in such a manner to recognize some indeterminism or free will [17]. Thus, there is hardly a clear and strict conception of determinism during the Ancient period. The same, actually, holds for the notion of rights, which can hardly be identified with the modern human rights doctrine [18].

\section{Grotius: Modern Stoicism}

Based on a vast enquiry into the Old Testament, the New Testament and Greek-Roman philosophy with almost endless quotes, Hugo Grotius arrived at pinning down the essence of modern Stoicist natural law thinking [19], namely the following properties of mankind and its immunities:

1) Sociability of humans; 2) not harming others or taking their belongings; 3 )

compensate for damages inflicted upon others: 4) "pacta sunt servanda".

Grotius finds these 4 principles to be valid for individuals in domestic affairs and states in international affairs, because they are Right Reason:

(Q1) IX. From this Signification of Right arose another of larger Extent. For by reason that Man above all other Creatures is endued not only with this Social Faculty of which we have spoken, but likewise with Judgment to discern Things 1 pleasant or hurtful, and those not only present but future, and such as may prove to be so in their Consequences; it must therefore be agreeable to human Nature, that according to the Measure of our Understanding we should in these Things follow the Dictates of a right and sound Judgment, and not be corrupted either by Fear, or the Allurements of present Pleasure, nor be carried away violently by blind Passion. And whatsoever is contrary to such a Judgment 2 is likewise understood to be contrary to Natural Right, that is, the Laws of our Nature [19].

This Right Reason philosophy is to be found with several political theorists over these three centuries in one version or another, with Lipsius, Locke, Rous- 
Table 2. Moralism versus naturalism.

\begin{tabular}{ll}
\hline \multicolumn{1}{c}{ Moralism } & \multicolumn{1}{c}{ Naturalism } \\
\hline 1) Altruism & Egoism, power \\
2) Respect other's property & Obey only positive law \\
3) Compensate for damages done & Only if court rules so \\
4) "Pacta sunt servanda" & Rational cheating \\
& \\
\hline
\end{tabular}

seau and Paine [20] (Finnis, 2011). Thomas Hobbes rejected moralism in his Leviathan, stating the case for naturalism, i.e., "Laws" in the sense of scientific law, or law-like regularities in Nature refers to the IS, or the discovery of the laws of the Universe and the living organisms, with e.g. Newton and Darwin [21]. To Hobbes, legal laws are merely the commands of the sovereign, never moral laws. Spinoza argues similarly.

The Renaissance initiated the search for these natural regularities, Aristotelian teleology. A number of prominent political thinkers have tried to formulate laws politics without moral connotations, emphasizing not rights and altruism but power and egoism. Thus, we have the following two themes-Table 2.

It should be emphasized that Grotius derives the four principles of altruism or sociability from universal right reason together with the Jewish-Christian and Greek-Roman philosophy and Roman jurisprudence. He then applied them to both humans and human society, domestically and the international system of states, laying the foundations of public international law.

We find these sub-themes with many political philosophers from the Pre-Socrates over Nietsche to modern political theory.

\section{Spinoza: Modern Epicurism}

Spinoza admits choice, but rejected indeterminism or freedom of will [22] [23], i.e. especially choice with regard to the political regime that promotes general welfare, peace and security. Spinoza is not only one of $10-15$ greatest philosophers in the West due to his Ethics [24] [25]. He is also a major politician theoretician as a result of his two treatises, where Tractatus Politicus is much underestimated.

It is 4 always stated that Spinoza adheres to rationalism with inspiration from Stoicism and Descartes; but the influence from Hobbes is obvious, but seldom pointed out [26]. There has been a debate about what Spinoza meant with "nature", especially when he equates the word with "God". Was he an atheist, as the Jewish community accused him, or a pantheist? [27] He states:

(Q1) And so by natural right I understand the very laws or rules of nature, in accordance with which everything takes place, in other words, the power of nature itself. And so the natural right of universal nature, and consequently of every individual thing, extends as far as its power: and accordingly, whatever any man does after the laws of his nature, he does by the highest natural right, and 
he has as much right over nature as he has power [28].

In this key passage, Spinoza confirms his naturalism from Ethics, meaning that everyone does whatever he or she wants. Society is a condition of "natural rights", meaning power or lack of power. Several commentators have interpreted this naturalism as a form of Stoicism, which is erroneous. Spinoza declines every theory of human rights as natural legal rights. Spinoza speaks of "natural rights" without any legal connotation, as simply natural capacities to safeguard whatever interests a human being may have. We are far from Stoicism and its natural rights conception, as a matter of fact much closer to Epicurism of the two great ethical theories during the Ancient period.

Spinoza rejects completely Stoicist conceptions of human rights, social harmony and the universal soul of all human beings. Thus, we read:

(Q2) From which it follows that the law and ordinance of nature, under which all men are born, and for the most part live, forbids nothing but what no one wishes or is able to do, and is not opposed to strifes, hatred, anger, treachery, or, in general, anything that appetite suggests. For the bounds of nature are not the laws of human reason, which do but pursue the true interest and preservation of mankind, but other infinite laws, which regard the eternal order of universal nature, whereof man is an atom; and according to the necessity of this order only are all individual beings determined in a fixed manner to exist and operate [29].

This amounts to the message of Epicurus! Society without government is the Hobbesian jungle. Remember that Leviathan was published in 1651, before Tractatus Politicus. People are bound by nothing in society, as any notion of "Pacta sunt servanda" is foolishness merely.

We could not be further away from the Stoicsts like Grotius, Locke and Kant. This is a 17th century version of Epicurism. He distinguishes between "natural rights" and "legal rights", where the former stands for capacity or power and the latter for the ordinances of the commonwealth. Men and women are guided by emotions and reason in the pursuit of self-preservation-enlightened egoism.

Spinoza is perhaps most famous for his determinism that he derives with his Euclidean method-more geometrico [30]. Let us try to pin down this thesis and then inquire into whether it is in agreement with his political arguments, or whether there is a contradiction. His version of determinism reads as follows in a few quotations from the Ethics:

(Q3) In nature there is nothing contingent, but all things have been determined from the necessity of the divine nature to exist and produce an effect in a certain way [31].

(Q4) Things could have been produced by God in no other way, and in no other order than they have been produced [32].

These propositions have been discussed a lot in the Spinoza literature. They raise questions about free will, indeterminism and voluntarism. Since Spinoza argues that God is part of this determinism, it also leads to a debate about his theology or pantheism [33]. 
In Tractatus Politicus, Spinoza first sticks to his naturalism and determinism from Ethics, spelling out there implication for politics. There is no covenant, and no choice of a regime, as all unfolds from the determinism of nature, or "God" as Spinoza says. Spinoza is not a contractarian philosopher. The state is not based upon any contractual choice but upon natural necessity. Just as an individual is driven by the ambition to survive-principle of conatus, so groups of individuals do the same also when they constitute a dominion, or commonwealth. Just like human beings, they augment survival capacity by employing reason, informing the political authority to promote general well-being, or face competition from another commonwealth. Spinoza rejects any choice of opposition or rebellion against the political authority, claiming that people are "bound" to obey. However, such a duty cannot be housed within naturalism. Here, Spinoza breaks with Hobbes.

Secondly, Spinoza is a strong adherent of institutionalism. It is the framing of the institutions that keeps the commonwealth on its right track towards peace and security. He engages in a minute examination of the adequate institutions that reason devises. His model is that the dominion is rule by one person, a few persons or all the people. Every type of dominion can only achieve the natural goals of a commonwealth, namely general well-being. The argument in Spinoza' political theory is aimed at political realism and avoids moralism. It is much built up upon his theory of human nature, or how people really behave. They are what they are, and can only be restrained by rules:

(Q5) Institutionalism: A dominion then, whose well-being depends on any man's good faith, and whose affairs cannot be properly administered, unless those who are engaged in them will act honestly, will be very unstable. On the contrary, to insure its permanence, its public affairs should be so ordered, that those who administer them, whether guided by reason or passion, cannot be led to act treacherously or basely [34].

Spinoza's Tractatus Politicus offers a vast and intriguing enquiry into incentives and institutions that reminds of the principal-agent modelling in the economics of asymmetric information. It is free from any metaphysical assumptions about natural rights in the Stoicist-Locke-Nozick tradition. Naturalism is the basis, coupled with determinism [35] (Russell, 1984). When determinism appears not sufficient, then is Spinoza right in claiming that this involves a mere ignorance? Is free will incompatible with determinism, and thus a Spinoza illusion [36]? Is institutionalism compatible with strict determinism? I am doubtful. Spinoza's institutionalism may break with his determinism opening for choice and maybe the freedom of the will.

\section{Helvetius and Holbach: Coherent Determinism}

Much underrated both, the two French philosophers Helvetius and Holbach developed an original and coherent version of Epicurism. They argued from an atomistic universe to a coherent hedonistic view of men and women. They 
taught atheism of course, but failed to endorse political democracy. Let us take a few quotes:

(Q1) Self-interest, founded on the love of pleasure and the fear of pain, is the sole spring of judgment, action, and affection. Human beings are motivated solely by the pursuit of pleasure and the avoidance of pain. These two are, and always will be, the only principles of action in man [37].

(Q2) There is but one man who can believe himself free from envy; and it is he who has never examined his own heart [38].

(Q3) Every man without passions has within him no principle of action, nor motive to act [39].

(Q4) Education made us what we are [40].

(Q5) The universe, that vast assemblage of every thing that exists, presents only matter and motion: the whole offers to our contemplation, nothing but an immense, an uninterrupted succession of causes and effects [41].

(Q6) What, indeed, is an atheist? He is one who destroys delusions which are harmful to humanity in order to lead men back to nature, to reality, to reason. $\mathrm{He}$ is a thinker who, having reflected on the nature of matter, its energy, properties and ways of acting, has no need of idealized powers or imaginary intelligences to explain the phenomena of the universe and the operations of nature [42].

(Q7) The inward persuasion that we are free to do, or not to do a thing, is but a mere illusion. If we trace the true principle of our actions, we shall find, that they are always necessary consequences of our volitions and desires, which are never in our power. You think yourself free, because you do what you will; but are you free to will, or not to will; to desire, or not to desire? Are not your volitions and desires necessarily excited by objects or qualities totally independent of you [43]?

The combination of naturalism and determinism is most impressive with these two French scholars. It is all strict Epicureanism, i.e. atomism, hedonism, atheism. The political implications of coherency are enlightened government with an emphasis upon education for the people. The political implications of their basic utilitarianism were hardly revolutionary, but Holbach developed a contract theory in two steps, allowing for the removal of the sovereign if he failed to promote general welfare.

It is time to turn to a few voluntarist philosophers with a more complex view of humans, allowing especially for free will.

\section{Kierkegaard: Peaceful Voluntarism}

S. Kierkegaard is a great exponent of voluntarism. He also adheres to naturalism. His famous quotes spell out indeterminism. His interpreters place him as a somewhat confused philosopher, haunted by unfulfilled love for a woman, Regine, or as struggling in vain to accommodate Christianity with reason and humbleness [44]. To me, he presents a coherent message about the freedom of 
will and the life necessity of choice.

(Q1) It is perfectly true, as the philosophers say, that life must be understood backwards. But they forget the other proposition, that it must be lived forwards [45].

(Q2) Freedom's possibility is not the ability to chose the good or the evil. The possibility is to be able. In a logical system, it is convenient to say that possibility passes over into actuality. However, in actuality it is not so convenient, and an intermediate term is required. The intermediate term is anxiety, but it no more explains the qualitative leap than it can justify it ethically. Anxiety is neither a category of necessity nor a category of freedom; it is entangled freedom, where freedom is not free in itself but entangled, not by necessity, but in itself [46].

(Q3) I was brought up in the Christian religion, and although I can scarcely sanction all the improper attempts to gain the emancipation of woman, all paganlike reminiscences also seem foolish to me. My brief and simple opinion is that woman is certainly as good as man-period. Any more discursive elaboration of the difference between the sexes or deliberation on which sex is superior is an idle intellectual occupation for loafers and bachelors [47].

(Q4) Where is the boundary for the single individual in his concrete existence between what is lack of will and what is lack of ability; what is indolence and earthly selfishness and what is the limitation of finitude? For an existing person, when is the period of preparation over, when this question will not arise again in all its initial, troubled severity; when is the time in existence that is indeed a preparation? Let all the dialecticians convene-they will not be able to decide this for a particular individual in concreto [48].

In reality, Kierkegarrd is the first systematic explorer of the principle of free will and its entailment for philosophy. His many books, written feverishly during a short period of time, examine the implications of free will: anxiety, responsibility, feelings of remorse and debt regret, egoism, religious belief, etc. His complete rejection of Hegelianism in Berlin is quite understandable, as he regarded macro determinism as wrong as micro determinism. He discovered the autonomy of freedom.

The famous Kierkegaard distinction between ex ante determinism and ex post indeterminism is helpful here:

\begin{tabular}{cccc}
\hline & & Explaining & Prediction \\
\hline \multirow{2}{*}{ Determinism } & Ex ante & I & II \\
& Ex post & III & IV \\
\hline
\end{tabular}

Kierkegaard accepts one type of determinism, Type III, but rejects the other types, I, II, IV. For him, it is not an epistemological fact but an ontological one, because the path of life can be chosen looking forward, correctly or wronglyKierkegaard's (1992): Either-Or [49].

\section{Nietzsche: Philosopher of Aggressive Voluntarism}

Much has been written about F. Nietzsche, defending him or attacking him. From the point of view in my approach, Nietzsche is strongly indeterminist but 
also an exponent of naturalism - an extreme voluntarist. Here, I will take some quotes from his later publication to show that he preached a rather aggressive form of voluntarism-and naturalism, making him very different from Kierkegaard, who preceded him in time.

It is true that several scholars have interpreted Nietzsche as a less aggressive philosopher, who merely preached a sincere re-evaluation of established morals in favour of truth and sincerity. However, in his later books, Nietsche argues for a most assertive kind of voluntarism:

(Q1) You have your way. I have my way. As for the right way, the correct way, and the only way, it does not exist [50].

(Q2) Christianity is called the religion of pity. Pity stands opposed to the tonic emotions which heighten our vitality! It has a depressing effect. We are deprived of strength when we feel pity. That loss of strength which suffering as such inflict on life is still further increased and multiplied by pity. Pity makes suffering contagious. Under certain circumstances, it may engender a total loss of life and vitality out of all proportion to the magnitude of the cause... [51]

(Q3) "Judgments, judgments of value, concerning life, for it or against it, can, in the end, never be true: they have value only as symptoms, they are worthy of consideration only as symptoms; in themselves such judgments are stupidities. One must by all means stretch out one's fingers and make the attempt to grasp this amazing finesse, that the value of life cannot be estimated." [52]

(Q4) Suppose, finally, we succeeded in explaining our entire instinctive life as the development and ramification of one basic form of the will-namely, of the will to power, as my proposition has it... then one would have gained the right to determine all efficient force unequivocally as--will to power. The world viewed from inside ... it would be "will to power" and nothing else [53].

(Q5) Against that positivism which stops before phenomena, saying "there are only facts," I should say: no, it is precisely facts that do not exist, only interpretations ... [54]

Nietzsche developed a strong voluntarism that not only covered naturalism but also an emphasis upon subjectivism in epistemology. Thus, he anticipates post-modernism. Moreover, he underlines individualism to such an extent that he becomes a critique of equality and democracy. His preaching of the "Superman" and the "will to power" is not merely a forceful way of rejecting traditional Christian and Jewish moralism, but invites one also maybe to walk the road towards the sublimation of force, physical force into voluntarism.

\section{Naturalism and Moralism in Rawls and Dworkin}

In the debate about political philosophy after the Second World War, the tone is distinctly different from political though in the first haft of the $20^{\text {th }}$ century. The focus is now much upon rights of all kinds, as in Nozick reviving Locks's innate and inalienable rights and little upon needs or power [55]. Interesting, the first major theoretician of justice, Rawls, tried actually to found his list of rights upon 
a realistic theory of choice under ignorance. With Dworkin, we turn basically in a world of Platonic ideas. Justice IS this or that, we hear, but they mean simply: Justice OUGHT to be X, or Y, or Z. Normative political theory completely lacks a meta-ethical foundation.

As a matter of fact, Nozick never gave any foundation for his starting-point of theorizing, namely that human beings have rights. He merely assumes this, just as Locke invoked divine origin. "Rights" is an ambiguous word, as moral philosophy employs it normative, whereas ordinary jurisprudence uses it theoretically to describe a legal system, in accordance with Hohfeld's scheme. Naturalists in the $20^{\text {th }}$ century have claimed that rights do not exist, when thinking about normative rights [56], whereas normative legal philosophy makes rights its core set of concepts [57].

\subsection{Rawls' Naturalism}

Rawls developed his theory of justice, integrating various other concepts in consecutive books and articles [58]. Here, there is only space for considering his original criteria of justice and its theoretical motivation. Firstly, we have the criteria:

(Q1) First Principle: Each person has the same indefeasible claim to a fully adequate scheme of equal basic liberties, which scheme is compatible with the same scheme of liberties for all;

(Q2) Second Principle: Social and economic inequalities are to satisfy two conditions:

a) They are to be attached to offices and positions open to all under conditions of fair equality of opportunity,

b) They are to be to the greatest benefit of the least-advantaged members of society (the difference principle) [59].

I will call the first principle "liberty under the rule of law" and the second one "equality under maxim in". Both sets of criteria need no explication but can be applied both to political regimes and in public policies. The maxim in principle was radical at the time when liberalism or public choice dominated. It separated Rawls from the classical liberalism or neo-liberalism of Hayek and Nozick for instance.

Rawls justice criteria called for both liberty and equality-thus "liberal egalitarianism". They were revolutionary for the political theory in the US but hardly much different than Social Democracy ideals in Europe. The originality with Rawls came with the argument for these two principles, namely choosing justice under a veil of ignorance.

The idea of a veil of ignorance is meant to meet the often made requirement that justice criteria are impartial, i.e. do not merely rationalize the person position of the chooser, endorsing the status quo if in a favourable position and calling changes in a negative position. In a veil of ignorance, the choosing person knows nothing, not even his/her personal characteristics-a remarkably strange 
construction

However, the is abstruse construction can be turned into a game of incomplete information where Nature makes the first move, putting a real person into a positive or negative position with regard to life opportunities. Fearing the negative position, a rational choice is to bet upon risk aversion, meaning choosing justice principles that institutionalise liberty under rule of law firstly and secondly equality under economic efficiency. Now, things make sense, as these choices are Nash equilibria.

Now, the only objection that may be raised within this deontological framework is to question risk aversion. Maybe the person could be risk prone? Then Rawls' theory collapses. In the Weberian approach, these two choices will be made on the basic of values, or subjective evaluations morally.

Rawls' solution-the first and second principles of justice-is based upon the model of a game against nature in the so-called state of nature where people act under a veil of ignorance. Rawlsianism as a moral philosophy belongs under rational choice, as it is in reality based upon a double game against Nature. What would ordinary person $\mathrm{P}$ choose if he/she is under a veil of ignorance-see the dotted line in Figure 1 and Figure 2?

In the first game concerning freedom, the actor will chose the maxmin, as he/she faces complete uncertainty about whether he/she is at the upper or lower node. The worst outcome-subjection-must be avoided.

In the second game that deals with the distribution of resources, the actor will again take maxmin, choosing the welfare state ahead of the welfare society, because he/she does not know which node he/she is at, upper or lower.

Since Rawls assumes that ordinary people are risk avert, it follows that they

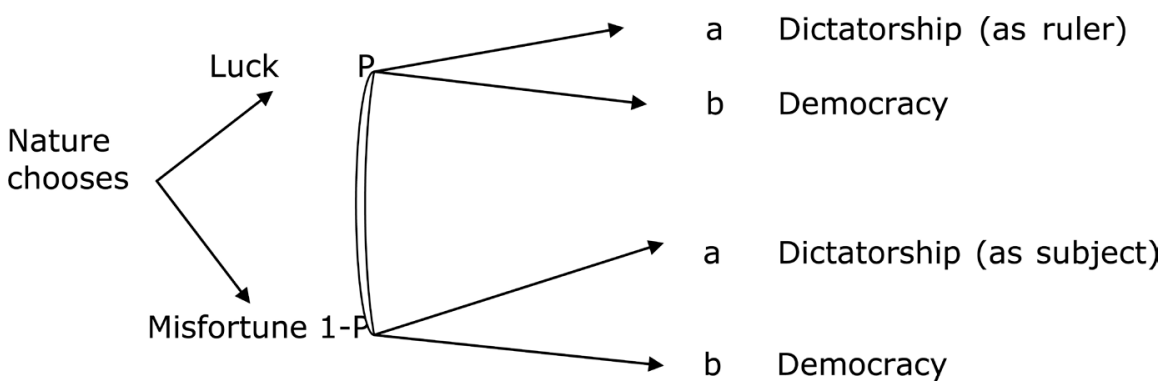

Figure 1. Rawls'first game-freedom under rule of law.

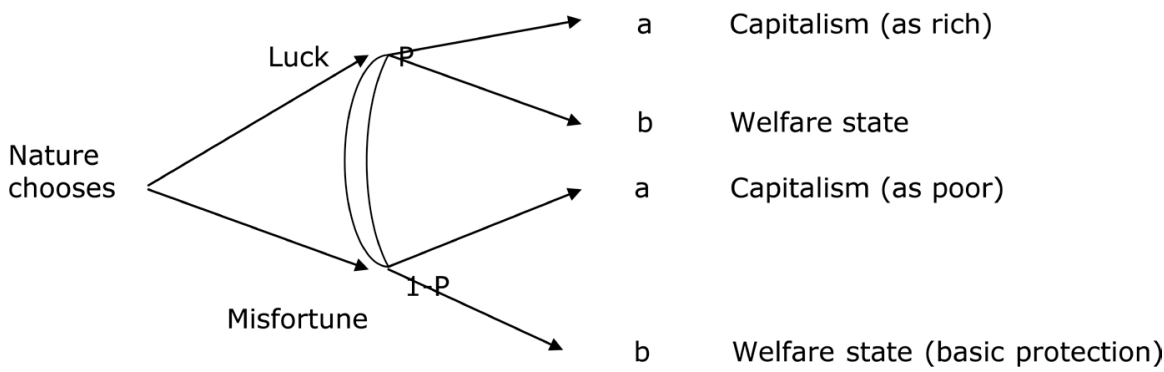

Figure 2. Rawls'second game-equality under efficiency. 
will never choose a risky strategy, preferring democracy to dictatorship and the welfare state to unrestrained capitalism. However, these moral conclusions about liberty under rule of law and equality with economic efficiency hold only under this naturalistic assumption, as risk prone people may prefer to gamble for the maxmax.

\subsection{Dworkin’s Moralism}

Dworkin looks upon the key terms like "justice", "rights" and "entitlements" from the point of view of normative jurisprudence. As a matter of fact, law and morals are inseparable. Thus, rights always constitute normative trumps, i.e. what people can rightfully claim from government. Let me quote:

(Q1) Moral principle is the foundation of law [60].

(Q2) Without dignity our lives are only blinks of duration. But if we manage to lead a good life well, we create something more. We write a subscript to our mortality. We make our lives tiny diamonds in the cosmic sands [61].

Compare this extreme moralism with Nietzsche's naturalism! The difficulty with dogmatic assertions like these Dworkin quotations is that there is not ONE morality, like a Platonic idea in the ideal world. Typically, there is conflict among the moralities people adhere to. Why would Dworkin's morality-liberal egalitarianism-be THE morality? There is always conflict over basic moral principles. Morals are contestation. Law is ambiguity and incompleteness, as Posner argues.

Typical of all Dworkin has written is the confusion of IS and OUGHT. What is the foundation of what law? What morals? Whose morals? Chinese law, South African law, Common or Civil Law?

When we are told to take "right seriously", what rights are we talking about: Hayekian rights regulating laissez faire [62], Barry's impartiality that is conducive to democratic socialism, etc. [63]. The debate over natural law-ordinary law still continues, with Dworkin as its strongest adherent today. His chief critique R. A. Posner today argues that natural law according to (Q1) and (Q2) is merely a set of moral prescriptions, and not LAW at all [64] [65]. I agree with Posner in his rejection of Dworkin's confusion of jurisprudence and moral philosophy. If Dworkin managed to smash legal positivism of Hart's kind with his rejuvenated natural law philosophy, he certainly did not crush the other alternatives, legal realism and legal pragmatism. Law is not a set of Platonic ideas, as jurisprudence is a practical discipline.

\subsection{Justice as Envy Freeness}

Dworkin developed his version of liberal egalitarianism, focussing upon the concept of envy and the policy implications of the requirement of justice = envy freeness. It led him to a very original theory of auctions and insurance. However, it has little relevance for the basic problematic of enhancing real equality in social life-Dworkin's goal [66]. A society and polity based upon envy freeness is completely impractical. Social justice can never start from scratch at an isolated 
island and neglect merit, which is what Dworkin tries to bypass with the utopian auction and the unrealistic insurance scheme. Dworkin's moralism is utopian.

\section{Conclusions}

The themes for analyzing political thought chosen here seem fertile. A number of prominent political philosophers are within the reach of this approach, also a genuine philosopher like the Great Dane, Kierkegaard. The basic problem of the freedom of the will remains, however, a puzzle. Political theory only based upon rights degenerates into moralism and wishes, i.e. utopianism, towards which a dose of naturalism and determinism is a proper antidote.

One may wish to separate strong determinism from weak determinism:

1) Everything is determined;

2) Some things or events are determined.

Similarly, one may separate strong voluntarism from weak voluntarism:

3) Human volition is entirely free, i.e. a human can do whatever is possible;

4) Human action is free to the extent that it agrees with the model of rational choice, i.e. it is based upon individual preferences and available information.

\section{References}

[1] Wolin, S. (1960) Politics as Vision. Little, Brown and Co., New York.

[2] Hacker, A. (1961) Political Theory: Philosophy, Ideology and Science. MacMillan, New York.

[3] Early Hook, S. (1958) Determinism and Freedom in the Age of Modern Science. Collier-Macmillan, New York.

[4] Earman, J. (1986) A Primer on Determinism. Springer, Berlin.

[5] Popper, K.R. (2000) The Poverty of Historicism. Routledge, London.

[6] Riker, W. and Ordeshook, P. (1973) An Introduction to Formal Political Theory. Prentice-Hall, New York.

[7] Hastie, R. and Dawes, R.M. (2009) Rational Choice in an Uncertain World: The Psychology of Judgment and Decision Making. 2 Edition, SAGE Publications, Inc., London.

[8] Skinner, Q. (2002) Visions of Politics: Volume 3. CUP, Cambridge.

[9] Plamenatz, J. (1992) Man and Society: Political and Social Theories from Machiavelli to Marx from the Middle Ages to Locke: From the Middle Ages to Locke Vol. 1. Longman, London.

[10] Tuck, R. (2010) Natural Rights Theories: Their Origin and Development. CUP, Cambridge.

[11] Laws of Science. https://en.wikipedia.org/wiki/Laws_of_science

[12] Oxford English Dictionary Quote: “According to Natural Law Ethical Theory, the Moral Standards That Govern Human Behavior Are, in Some Sense, Objectively Derived from the Nature of Human Beings."

[13] Hohfeld, W.N. (1917) Fundamental Legal Conceptions as Applied in Judicial Reasoning. The Yale Law Journal, 26, 710-770. https://doi.org/10.2307/786270

[14] Pigden, C.R. (1990) Ought-Implies-Can: Erasmus Luther and R.M. Hare. Sophia, 29, 2-30. https://doi.org/10.1007/BF02782712 
[15] Long, A.A. and Sedley, D.N. (1987) The Hellenistic Philosophers. Vol. 1, CUP, Cambridge.

[16] Long, A.A. and Sedley, D.N. (2012) The Hellenistic Philosophers: Volume 2, Greek and Latin Texts with Notes and Bibliography. CUP, Cambridge.

[17] Bobzien, S. (2002) Determinism and Freedom in Stoic Philosophy. Clarendon Press, Oxford.

[18] Garrett, J.E. (2008) The Doubtful Descent of Human Rights from Stoicism. Nordic Journal of Human Rights, 26, 77-90.

[19] Grotius, H. (1625) De jure belli et pacis. [On the Laws in War and Peace.] 137-140. http://oll.libertyfund.org/pages/grotius-and-the-laws-of-war

[20] Finnis, J. (2011) Natural Law and Natural Rights. 2nd Edition, Oxford University Press.

[21] Skinner, Q. (2008) Hobbes and Republican Liberty. CUP, Cambridge.

[22] Wolfe, R. (2008) Substance, Causation and Free Will in Spinoza and Leibniz. Arché, 2, 11-24.

[23] Lucero-Montaño, A. (2012) Spinoza's Ethics: Freedom and Determinism. https://ssrn.com/abstract=2010571

[24] Garrett, D. (1996) The Cambridge Companion to Spinoza. Cambridge University Press, Cambridge and New York.

[25] Nadler, S. (2001) Spinoza: A Life. Cambridge U.P., Cambridge.

[26] Nadler, S. (2016) Baruch Spinoza. The Stanford Encyclopedia of Philosophy, Fall 2016 Edition. https://plato.stanford.edu/archives/fall2016/entries/spinoza/

[27] Hampshire, S. (2007) Spinoza and Spinozism. Penguin, London.

[28] Spinoza, B. A Political Treatise [Tractatus Politicus]/Translated by R. H. M. Elwes, ebooks@Adelaide. https://ebooks.adelaide.edu.au/s/spinoza/benedict/

[29] Spinoza, B. A Political Treatise [Tractatus Politicus]/Translated by R. H. M. Elwes, ebooks@Adelaide. (Chapter II, Paragraph 4)

https://ebooks.adelaide.edu.au/s/spinoza/benedict/

[30] Byrne, L. (2007) The Geometrical Method in Spinoza's Ethics. Poetics Today, 28, 443-474. https://doi.org/10.1215/03335372-2007-004

[31] Spinoza, B. (2014) The Ethics [Ethica Ordine Geometrico Demonstrata]. Translated from the Latin by R. H. M. Elwes. (Proposition 29) https://ebooks.adelaide.edu.au/s/spinoza/benedict/ethics/

[32] Spinoza, B. (2014) The Ethics [Ethica Ordine Geometrico Demonstrata]. Translated from the Latin by R. H. M. Elwes. (Proposition 33) https://ebooks.adelaide.edu.au/s/spinoza/benedict/ethics/

[33] Jousse, E. (2004) The Idea of God in Spinoza's Philosophy. A Study about Its Definition, Influences and Impact Based on the First Part of Ethics at E-Logos.

[34] Spinoza, B. A Political Treatise [Tractatus Politicus]/Translated by R. H. M. Elwes, ebooks@Adelaide. (Chapter I, Paragraph 6) https://ebooks.adelaide.edu.au/s/spinoza/benedict/

[35] Russell, J.M. (1984) Freedom and Determinism in Spinoza. Thumbnail. Auslegung, 11, 378-389.

[36] Lloyd, G. (2001) Spinoza. Critical Assessments of Leading Philosophers. Routledge, London.

[37] Helvétius, C.A. (1810) Treatise on Man: His Intellectual Faculties and His Education. Transl. W. Hooper, Albion Press, London, 146. 
[38] Helvétius, C.A. (1810) Treatise on Man: His Intellectual Faculties and His Education. Transl. W. Hooper, Albion Press, London, 290.

[39] Helvétius, C.A. (1810) Treatise on Man: His Intellectual Faculties and His Education. Transl. W. Hooper, Albion Press, London, 43.

[40] Helvétius, C.A. (1810) Treatise on Man: His Intellectual Faculties and His Education. Transl. W. Hooper, Albion Press, London.

[41] Holbach, P.H.T. (1734) Nature, and Her Laws: As Applicable to the Happiness of Man. 17.

[42] Holbach, P.H.T. (1868) The System of Nature. Vol. 1, Batoche Books.

[43] Holbach, P.H.T. (1772) Good Sense, or Natural Ideas Opposed to Supernatural. 66.

[44] Garff, J. (2007) Soeren Kierkegaard. Princeton University Press, Princeton.

[45] Kierkegaard, S. (2011) Journals and Notebooks IV. Princeton U.P., Princeton, A164

[46] Kierkegaard's Writings, Vol. 8: Concept of Anxiety. Princeton U.P., Princeton, 49.

[47] Kierkegaard's Writings, Vol. 11: Stages on Life's Way. Princeton U.P., Princeton, 124.

[48] Kierkegaard, S. (1992) Concluding Unscientific Postscript, Eds., Hong and Hong, 490, 451.

[49] Kierkegaard, S. (1992) Either or: A Fragment of Life. Penguin, London.

[50] Nietzsche, F. (2017) Thus Spoke Zarathustra. CreateSpace, London.

[51] Nietzsche, F. (2016) The AntiChrist. CreateSpace, London.

[52] Nietzsche, F. (2012) Twilight of the Idols. CreateSpace, London.

[53] Nietzsche, F. (2003) Beyond Good and Evil. Penguin, London.

[54] Nietzsche, F. (1994) The Portable Nietzsche. Penguin, London, 458.

[55] Nozick, R. (1974) Anarchy, State, and Utopia. Basic Books, New York.

[56] Ross, A. (2011) On Law and Justice. The Lawbook Exchange, London.

[57] Dworkin, R. (1977) Taking Rights Seriously. Harvard University Press, Cambridge.

[58] Rawls, J. (2001) Justice as Fairness: A Restatement. Harvard U.P., Cambridge.

[59] Rawls, J. (1971) A Theory of Justice. Harvard U.P., Cambridge.

[60] Dworkin, R. (1986) Law’s Empire. Harvard University Press, Cambridge.

[61] Dworkin, R. (2011) Justice for Hedgehogs. Harvard U.P., Cambridge.

[62] Hayek, F. (1980) The Constitution of Liberty. Routledge, London.

[63] Barry, B. (1993) Justice as Impartiality. Oxford U.P., Oxford.

[64] Posner, R.A. (1993) The Problems of Jurisprudence. Harvard University Press, Cambridge.

[65] Posner, R.A. (2003) The Problematics of Moral and Legal Theory. Belknap Press, Cambridge.

[66] Dworkin, R. (2000) Sovereign Virtue. Harvard U.P., Cambridge. 
Submit or recommend next manuscript to OALib Journal and we will provide best service for you:

- Publication frequency: Monthly

- 9 subject areas of science, technology and medicine

- Fair and rigorous peer-review system

- Fast publication process

- Article promotion in various social networking sites (LinkedIn, Facebook, Twitter, etc.)

- Maximum dissemination of your research work

Submit Your Paper Online: Click Here to Submit

Or Contact service@oalib.com 